\title{
Assessment of water loss level on the example of selected distribution systems
}

\author{
Ewa Ociepa ${ }^{1, *}$, Robert Molik ${ }^{2}$, and Joanna Lach $^{1}$ \\ ${ }^{1}$ Czestochowa University of Technology, Faculty of Infrastructure and Environment, Brzeźnicka 60a, \\ 42-200 Częstochowa, Poland \\ ${ }^{2}$ Water Supply and Sewerage Company in Radomsko, Krzywa 12, Poland
}

\begin{abstract}
One of the major problems of waterworks is the excessive failure of distribution systems and associated water leaks. Water losses in water supply networks and systems are often a very high percentage of water supplied into the network. Therefore, a comprehensive analysis and assessment of water losses should be the basis for undertaking modernisation efforts to reduce the costs associated with water production and distribution. The article presents the analysis of water losses performed on the basis of data provided by the Water Supply and Sewerage Company in Radomsko. The data comprised the information on the water supply infrastructure and quantitative water balance for the period of 2010-2015. Based on the data, the following water loss indices were calculated: the percentage water loss (PWS) or non revenue water (NRW) index, real loss basic (RLB), non revenue water basic index (NRWB), unavoidable annual real losses (UARL) and infrastructure leakage index (ILI). The obtained results demonstrate that due to continuous actions in the recent years the Water Supply and Sewerage Company in Radomsko has reduced the water loss to the levels that correspond to the average water loss on national and international levels.
\end{abstract}

\section{Introduction}

Due to the optimisation of water production costs and the need to protect water resources, rational reduction of water losses must be a priority task for water supply companies. On the loss side, the resource cost and environmental costs of wasted water, and other leakage costs, such as buildings or roads subsidence, and even the costs of street traffic jams caused by the removal of the results of water supply systems breakdowns should be taken into account [1-4]. In addition, water companies must strive to optimise the costs of their operations to protect their service recipients from undue and excessive increases in water charges. By reducing the losses, plants can reduce the costs of the current network exploitation and save on the investment costs. Plants operating water distribution systems in Poland and in other European countries must implement and apply modern standards for water loss management.

\footnotetext{
* Corresponding author: eociepa@is.pcz.czest.pl
} 
That is why for several years, numerous countries, including Germany, Switzerland, Austria, Great Britain, Denmark and Spain, have been developing and implemented special programmes to thoroughly analyse the technical, economical and reliability indicators of water supply systems [5-8].

The purpose of the research presented in the article is to analyse and evaluate the water loss in the distribution system exploited by the Water Supply and Sewerage Company in Radomsko. The percentages of losses, unit indices with reference to the network length and to the inhabitants, and a unified international methodology based on the indicators recommended by IWA (International Water Association) were used to determine the water losses. The computed values of water loss indicators were compared with the data from the AWWA (American Water Works Association), IWA and WBI (Water Band Index). The obtained values of indicators for the discussed system were compared to the Polish and international standards.

\section{Research scope and methodology}

The analysis covered the data from the period of 2010-2015, obtained from the Water Supply and Sewerage Company in Radomsko, which included: water supplied to the network, used for social welfare purposes, non-production and production purposes, network length, quantity and length of water supply connections, material and age structure of the network, the number of recipients. Using this data the percentage ratio of water loss (NRW) and unitary loss per capita ratio ( $\mathrm{Q}_{\text {los }}$ ) were estimated, as well as the IWA recommended indicators [9]:

- Real Leakage Balance (RLB1 and RLB2)

- Non-Revenue Water Basic (NRWB)

- Unavoidable Annual Real Losses (UARL)

- Infrastructure Leakage Index (ILI)

The above ratios were calculated with the formulas 1-7 [9-11] using the data obtained from the water supply plant.

\section{Percentage Water Loss Indicator - NRW}

The use of this indicator allows to determine the percentage of water loss as compared to the water that was injected into the water supply. The percentage water loss indicator is determined depending on:

$$
\mathrm{NRW}=\left(\mathrm{V}_{\text {los }} / \mathrm{V}_{\text {sup }}\right) \cdot 100 \%
$$

$\mathrm{V}_{\text {los }}$ - water loss in the distribution system, $\mathrm{m}^{3} /$ year,

$\mathrm{V}_{\text {sup }}$ - water supplied to the network, $\mathrm{m}^{3} /$ year.

Unitary Loss Per Capita Indicator - Qlos

$$
\mathrm{Q}_{\mathrm{los}}=\left(\mathrm{V}_{\mathrm{los}} \cdot 1000\right) /(\mathrm{IN} \cdot 365)
$$

$\mathrm{Q}_{\text {los }}$ - Unitary Loss Per Capita Indicator, $\mathrm{dm}^{3} /$ inhabitant/day

IN - number of inhabitants using the water supply system.

\section{Unique Real Leakage Balance Indicator - RLB}

The RLB represents the amount of water loss taking into account the number of water connections, calculated according to the methodology presented below:

When the connection density is less than 20 per $\mathrm{km}$ of the water supply network, it shall be calculated with the formula:

$$
\mathrm{RLB} 1=\mathrm{V}_{\mathrm{los}} /[(\mathrm{M}+\mathrm{R}) \cdot 365]
$$

RLB1- Unique Real Leakage Balance Indicator, $\mathrm{m}^{3} /(\mathrm{km} \cdot$ day $)$

$\mathrm{M}$ - main network's length, $\mathrm{km}$

$\mathrm{R}$ - distribution pipes, $\mathrm{km}$. 
However, when the connection density exceeds $20 \mathrm{~km}$ per square meter, the water supply network shall be calculated according to the formula:

$$
\mathrm{RLB} 2=\left(\mathrm{V}_{\text {los }} \cdot 1000\right) /\left(\mathrm{L}_{\mathrm{wc}} \cdot 365\right)
$$

RLB2 - Unique Real Leakage Balance Indicator, $\mathrm{dm}^{3} /$ connection/day

$\mathrm{L}_{\mathrm{wc}}$ - number of house connections.

\section{Non-Revenue Water Basic Index - NRWB}

The determination of unprofitable water (unsold) is determined by the difference between the quantity of water produced and the quantity of water sold. Calculating the NRWB index allows to avoid distortions related to over-inflating the amount of water used for own purposes by some of the plants.

$$
\mathrm{NRWB}=\left[\left(\mathrm{V}_{\text {sup }}-\mathrm{V}_{\text {sol }}\right) / \mathrm{V}_{\text {sup }}\right] \cdot 100
$$

NRWB - Non-Revenue Water Basic Index, \%

$\mathrm{V}_{\text {sol }}$ - water sold, $\mathrm{m}^{3} /$ year.

\section{Unavoidable Annual Real Losses Indicator - UARL}

The Unavoidable Annual Real Losses (UARL) indicator defines the volume of losses that are considered unavoidable, since the detection of them is difficult and the removal of the cost is economically unprofitable. The amount of unavoidable leakage depends primarily on the length of the network, pressure and failure of the network and the number of recipients. Waterworks should establish an acceptable level of water loss. The UARL index is determined from the relation :

$$
\mathrm{UARL}=\left[18+(\mathrm{M}+\mathrm{R})+25 \cdot \mathrm{Wc}+0.8 \cdot \mathrm{L}_{\mathrm{wc}}\right] \cdot 0.365 \cdot \mathrm{p}
$$

UARL - Unavoidable Annual Real Losses Indicator, $\mathrm{m}^{3} /$ year

$\mathrm{W}_{\mathrm{c}}$ - length of house connection, $\mathrm{m}$

$\mathrm{p}$ - average pressure in the tested network ( $\mathrm{p}=46 \mathrm{~m} \mathrm{H}_{2} \mathrm{O}$ for the analysed plant)

0.365 - conversion factor per year and $\mathrm{m}^{3}$.

Infrastructure Leakage Index - ILI

The Infrastructural Leakage Index shows the multiplicity of actual water losses relative to the minimum (unavoidable) loss that can be achieved in a properly operated water supply system.

$$
\mathrm{ILI}=\mathrm{V}_{\text {los }} / \mathrm{UARL}
$$

\section{Water losses on the example of the Water Supply and Sewerage Company in Radomsko}

\subsection{General characteristics of the Company}

The Water Supply and Sewerage Company in Radomsko provides water for nearly $100 \%$ of the population (over 47 000) and numerous business entities. Only a few industrial plants have their own water intake for technological purposes. The whole water comes from underground water intakes. The water intake "Miłaczki" consists of eight deep wells with the depth of 51-110 m below ground level and the operating efficiency of $80-22 \mathrm{~m}^{3} / \mathrm{h}$.

It should be emphasised that the city of Radomsko is an industrial service and commercial centre, so water is delivered to numerous establishments and institutions. In addition, the industrial zone, of the Lodz Special Economic Zone, which also purchases water from the Water Supply and Sewerage Company in Radomsko, is developing fast.

\subsection{Characteristics of the water supply network}

The water supply system exploited by the plant is classified as a radial-and-ring system. Over the analysed period of six years, the length of networks and connections has increased 
steadily. However, this is a slow increase, among others, due to the fact that the number of inhabitants is decreasing (Table 1).

Most of the water supply pipes are made of PVC $-75 \%$, the remaining $25 \%$ are made of asbestos cement, cast iron and steel. The sections of the water supply made of asbestos cement, due to the lack of financial, are exchanged only during the reconstruction and modernisation of roads. The data from the plant indicate that the network failure rate is on average 0.99 fail./(km year).

Table 1. Characteristics of the water supply network.

\begin{tabular}{|c|c|c|c|c|}
\hline year & $\begin{array}{c}\text { number of } \\
\text { inhabitants using the } \\
\text { water supply system } \\
\text { (thousand) }\end{array}$ & $\begin{array}{c}\text { length of the water } \\
\text { supply network, } \\
\mathrm{M}+\mathrm{R} \\
(\mathrm{km})\end{array}$ & $\begin{array}{c}\text { length of house } \\
\text { connections, } \\
\mathrm{W}_{\mathrm{c}} \\
(\mathrm{km})\end{array}$ & $\begin{array}{c}\text { number of house } \\
\text { connections } \\
\mathrm{L}_{\mathrm{wc}}\end{array}$ \\
\hline 2010 & 48.20 & 146.82 & 112.05 & 6799 \\
\hline 2011 & 47.98 & 147.70 & 115.50 & 6880 \\
\hline 2012 & 47.95 & 153.97 & 118.22 & 6956 \\
\hline 2013 & 47.64 & 156.39 & 121.38 & 7047 \\
\hline 2014 & 47.40 & 158.22 & 122.68 & 7085 \\
\hline 2015 & 47.40 & 158.57 & 126.48 & 7194 \\
\hline
\end{tabular}

\subsection{Water balance and indicators characterising water losses}

Water balancing in the network is the basis for the operation of the water distribution system evaluation. On the basis of its results, the plants decide to initiate actions aimed at reduction of water losses. For accurate water balance and the determination of total water loss, on the basis of it, correct measurements are necessary:

- the amount of water input into the network,

- the quantity of water sold to all consumers,

- the amount of water taken for the needs of the water supply,

Only the water invoiced on the basis of indications of water meters or on a flat-rate basis brings income to an enterprise. The amount of water loss in the water supply network results from the difference between the water supplied to the network and the water sold and consumed for the needs of the water supply. Table 2 shows the data from the water balance in the analysed water company.

Table 3 and Fig. 1 Summarises the water loss indicators for the water supply system analysed as calculated from formulas 1-7.

The analysis of water loss took into account the hydraulic loads indicator of the network $\mathrm{Q}_{\mathrm{s}}, \mathrm{m}^{3} /(\mathrm{km} \cdot \mathrm{d})$. This indicator shows the average quantity of supplied water per day in reference to unit length of a water supply network. The indicator was calculated from the following formula [12]:

$$
\mathrm{Q}_{\mathrm{s}}=\mathrm{V}_{\text {sup }}(\mathrm{LM}+\mathrm{R} \cdot 365)
$$

Also, the hydraulic loads indicator indicator in reference $\mathrm{m}^{3} /(\mathrm{km} \cdot \mathrm{d})$ to the length of water supply network including the house connections was calculated from the following formula:

$$
\mathrm{Q}_{\mathrm{sL}}=\mathrm{V}_{\mathrm{sup}} /(\mathrm{L} \cdot 365)
$$


Table 2. Summary of water balance for the years 2010-2015.

\begin{tabular}{|c|c|c|c|c|c|}
\hline year & $\begin{array}{c}\text { water supplied } \\
\text { to the network, } \\
\text { thousand, } \\
\mathrm{m}^{3} / \text { year }\end{array}$ & $\begin{array}{c}\text { water for the } \\
\text { needs of the plant } \\
\text { thousand, } \\
\mathrm{m}^{3} / \text { year }\end{array}$ & $\begin{array}{c}\text { water sold, } \\
\text { thousand, } \\
\mathrm{m}^{3} / \text { year }\end{array}$ & $\begin{array}{c}\text { water loss in } \\
\text { the distribution } \\
\text { system, } \\
\text { thousand, } \\
\mathrm{m}^{3} / \text { year }\end{array}$ & $\begin{array}{c}\text { water for living } \\
\text { purposes, } \\
\mathrm{dm}^{3} / \text { (inhabitant } \text { day) }\end{array}$ \\
\hline 2010 & 2854.9 & 72.8 & 2126.9 & 655.2 & 85.4 \\
\hline 2011 & 2726.9 & 61.5 & 2112.0 & 553.4 & 85.4 \\
\hline 2012 & 2747.3 & 59.3 & 2153.9 & 534.1 & 84.7 \\
\hline 2013 & 2692.9 & 57.9 & 2113.9 & 521.1 & 83.4 \\
\hline 2014 & 2687.3 & 53.8 & 2149.8 & 483.7 & 83.2 \\
\hline 2015 & 2960.3 & 63.9 & 2320.9 & 575.5 & 85.6 \\
\hline
\end{tabular}

Table 3. Summary of water loss indicators for 2010-2015.

\begin{tabular}{|c|c|c|c|c|c|c|}
\hline year & $\begin{array}{c}\text { NRW } \\
\%\end{array}$ & $\begin{array}{c}\text { Qlos } \\
\mathrm{dm}^{3} / \text { (inhabitant·day) }\end{array}$ & $\begin{array}{c}\text { RLB1 } \\
\mathrm{m}^{3} / \mathrm{km} / \mathrm{day}\end{array}$ & $\begin{array}{c}\text { RLB2 } \\
\mathrm{dm}^{3} / \text { (connection·day) }\end{array}$ & $\begin{array}{c}\text { NRWB } \\
\%\end{array}$ & $\begin{array}{c}\text { UARL } \\
\mathrm{m}^{3} / \text { year }\end{array}$ \\
\hline 2010 & 22.9 & 37.0 & 12.2 & 268 & 25.5 & 182729 \\
\hline 2011 & 20.3 & 31.0 & 10.3 & 220 & 22.6 & 185546 \\
\hline 2012 & 19.4 & 30.5 & 9.5 & 210 & 21.6 & 189593 \\
\hline 2013 & 19.4 & 30.0 & 9.1 & 202 & 21.5 & 192877 \\
\hline 2014 & 18.0 & 28.0 & 8.4 & 187 & 19.9 & 194479 \\
\hline 2015 & 19.3 & 33.2 & 9.9 & 219 & 21.6 & 197652 \\
\hline
\end{tabular}

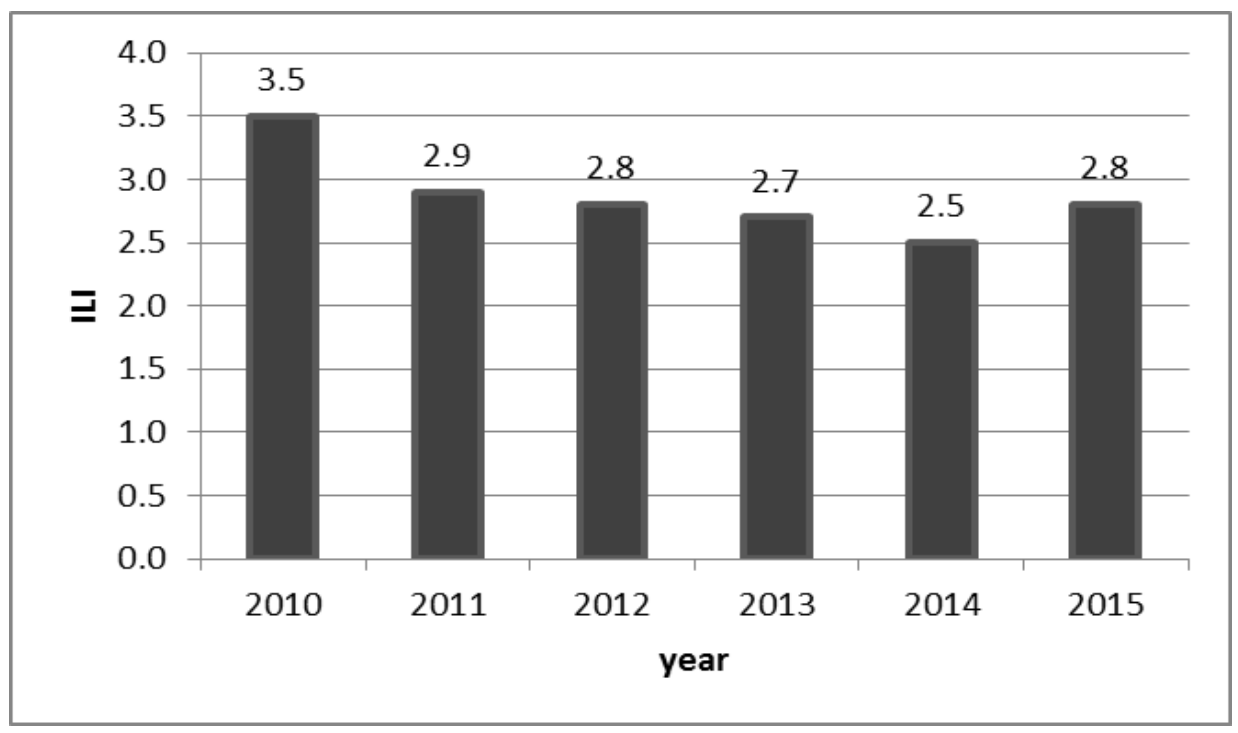

Fig. 1. Infrastructure Leakage Index (ILI).

The analysis of the data presented in tables 3 and 4 demonstrate that the values of the unit as well as percentage water loss depends on the hydraulic loads indicator. 
Table 4. Summary of indicators of individual hydraulic loads of water supply network in Radomsko.

\begin{tabular}{|c|c|c|c|c|c|c|}
\hline \multirow{2}{*}{ Indicator } & \multicolumn{7}{|c|}{ Year } \\
\cline { 2 - 7 } & 2010 & 2011 & 2012 & 2013 & 2014 & 2015 \\
\hline $\mathrm{Q}_{\mathrm{s}}, \mathrm{m}^{3} /(\mathrm{km} \cdot \mathrm{d})$ & 53.3 & 50.6 & 48.9 & 47.2 & 46.5 & 51.1 \\
\hline $\mathrm{Q}_{\mathrm{sL}}, \mathrm{m}^{3} /(\mathrm{km} \cdot \mathrm{d})$ & 30.2 & 28.4 & 27.7 & 26.6 & 26.2 & 28.5 \\
\hline
\end{tabular}

\section{Discussion of the results}

The article aims at performing an overall analysis of water loss in the system exploited by the Water Supply and Sewerage Company in Radomsko. It should be noted, however, that the amount of water consumed for the needs of the facility is indicative and some indicators may be subject to some error. The amount of water for own consumption is difficult and often impossible to measure (network rinsing, tanks, etc.), so most establishments assumes it to be an estimate.

The RLB1 and RLB2, NRWB, UARL, ILI were determined on the basis of the data obtained. The percentage loss of water was also calculated, although it is often criticised because it does not take into account such important factors as the length of the network, the number and length of connections and the pressure and hydraulic load of the water supply. For these reasons, it is not recommended to use it to compare water losses in different distribution systems. It can only be used to assess the variability of water losses in a longer-period in the same distribution system $[10,13]$. The determination of several loss indices over a 6-year period allowed for more accurate analysis and evaluation, and allowed for comparison with other investigations.

The percentage loss rate for the assessed plant in 2010 was about $23 \%$ and in 2015 it decreased to about $19 \%$. This indicated that the condition of the network was average comparing the available domestic data as the average value for this type of a system was about $24 \%$ [14]. The next indicator recommended by the IWA for comparison of the condition of water distribution systems is the RBL2 indicator, which in 2015 was approximately $219 \mathrm{dm}^{3} /$ (connection-day) which in comparison with the Polish systems confirms that the losses remain at the average level [15-17]. However, comparing it to the standards of the Western countries, where the permissible actual losses are assumed at $100 \mathrm{dm}^{3} /$ connection/day is unfavourable.

The average condition of the network is also defined by the Unitary Loss Per Capita Indicator the value of which in 2015 was $33 \mathrm{dm}^{3} /$ (inhabitant-day). According to Berger who analysed 334 group water supply works, this indicator was 24.0 to $39.9 \mathrm{dm}^{3} /$ (inhabitant day). The analysis of 10 municipal water supply systems performed by Hotloś [18] resulted in the average range of this indicator from 16 to $35 \mathrm{dm}^{3} /($ inhabitant $\cdot$ day).

The ILI is used for the comparison of various water distribution systems. It allows to classify the water supply network in terms of its technical condition. It also allows to individually evaluate whether losses under specified conditions of exploitation and at a given cost of lost water are at an acceptable or excessive level.

This indicator is currently the most effective parameter for assessing the efficiency of water distribution, however, it has its limitations. It is recommended to use it when the number of connections is greater than 5000 and their density exceeds 20 per km of water network and at the network pressure of at least $0.25 \mathrm{MPa}$. The ILI in 2010, for the analysed network was 3.5, and in 2015 its value reached 2.8. On the basis of this, it was found that the water supply was average while in 2010 it was weak (according to IWA). According to the AWWA and WBI criteria the value of ILI indicates that the condition of the network could be considered as satisfactory. It should be noted that when determining the ILI, actual 
as well as apparent water losses, such as water meter inaccuracies, are taken into account. The ILI values of $<2$ are recommended for the water supply works and they indicate a very good condition of a network. The ILI values of 2-4 indicate the need for improvement to enhance profitability with better network pressure management, active leakage control, and network maintenance $[9,10,19]$.

One of the most important indicators for assessing the technical condition of the network is connections failure. The severity of damage of the water supply network shall be calculated for one kilometre of the network over a period of one year. According to the data from the analysed plant, the value of this indicator in 2015 was 0.99 fail./(km·year). According to the European standards [PN-IEC 603000-3-4:2001], the repair is necessary if the damage indicator exceeds the values of 0.3 fail./(km.year) and 0.5 fail./(km.year) for the connections and distribution systems, respectively.

\section{Summary}

One of the basic principles of proper management of a modern water supply company is collecting as detailed information on the technical condition of the water supply and sewerage network as possible. Increasing requirements of the water supply recipients, with the preservation of the environment-friendly principles, have resulted in, among other things, the need to accurately determine and reduce water losses.

The calculated water loss rates have enabled the preliminary analysis and assessment of the technical condition of the water supply system and indicated that the investigated company has been working to reduce water losses in recent years. During the six-year period, the plant reduced water losses, as evidenced by a decrease in the percentage loss indicators, RBL, NRWB, ILI, and the unit water loss indices. At present, most indicators of water loss are at a good or average level. According to Bergel's extensive research indicates that the Polish waterworks supplying water to over 20 thousand inhabitants were mostly in average technical condition [16]. Many actions such as the ever-evolving monitoring, reduction and pressure stabilisation [20], repairs and replacement of the most emergency wires, have led to the reduction of leakage.

It is alarming to still see a fairly high network failure rate. Unfortunately, the authors of the publication did not have the structure of damage and could not demonstrate which sections of the network needed to be repaired, but it can be stated that due to the obtained results, the network needs continuous modernisation. Also, the average levels of ILI and RBL confirmed the value of conducting activities to increase the reliability of the distribution system. It should be stressed that the effects of the company's efforts to reduce the losses will be sustainable provided the systematic and continuous operation is maintained. As a result of long-term use of cast iron and steel pipes, they are broken, cracked, sealed at the joints, ejected pipes from the cups or corroded by the corrosion. Over time, the natural weakening of the material results in an increase in the failure rate of the water pipes. This is why the plant should continue its programme of systematic renewal and replacement of pipes and fittings (Pipe Materials Management).

This study was supported by BS/PB-401-301/17.

\section{References}

1. C. H. Ashton, V. S. Hope, Urban. Water. J. 3, 261 (2001)

2. C.K.M. Lee, J.S.L. Lam, Ind. Market. Manag. 41, 590 (2012)

3. G. Venkatesh, Probl. Ekorozw. 5, 2, 29 (2010) 
4. W. Kuczyński, W. Żuchowicki, Rocz. Ochr. Sr. 12, 419 (2010)

5. M. Clarke, P. Boden, A. McDonald, Water. Environ. J. 26, 292 (2012)

6. M. Clarke, S. B. Boden, Control. Eng. Pract. 12, 357 (2004)

7. O. Hug, A. Rödiger, R. Schaffert, S. Tippmann, Energie Wasser Praxis, 7(8), 2 (2002)

8. J.A. Zambrano, M. Gil-Martinez, M. Garcia-Sanz, I. Irizar, Water Sci. Technol. 60(2), 409 (2009)

9. A. Lambert, W. Hibner, The Blue Pages. Copyright by IWA, 10, 320 (2000)

10. M. Kwietniewski, Ochr. Sr. 35(4), 9 (2013)

11. F. Piechurski, Napędy i Sterowanie, 1, 68 (2014)

12. H. Hotloś, Ochr. Sr. 25(1), 17 (2003)

13. E. Ociepa, W. Kędzia, Inż. Ochr. Środ. 18(3), 277(2015)

14. T. Bergel, GWiTS. 8, 322 (2012)

15. P. Dohnalik, Z. Jędrzejewski, Efektywna eksploatacja wodociagów. Ograniczenie strat wody, to wcale nie trudne (Wyd. LEMTECH Konsulting, Kraków, 2004)

16. T. Bergel, GWiTS. 10, 413 (2012)

17. J. Rak, Ł. Sypień, JCEEA. 60(3/13), 5 (2013)

18. H. Hotloś, Ilościowa ocena wplywu wybranych czynników na parametry i koszty eksploatacji sieci wodociagowych. Monografia 49 (Ofic. Wyd. Politechniki Wrocławskiej, Wrocław, 2007)

19. G. Ferrari, D. Savic, Procedia Eng. 119, 189 (2015)

20. H. Hotloś, Environ Prot Eng. 36(3),103 (2010) 